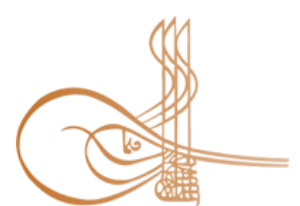

www.turkishstudies.net/education
Turkish Studies - Educational Sciences

eISSN: 2667-5609

Research Article / Araştırma Makalesi

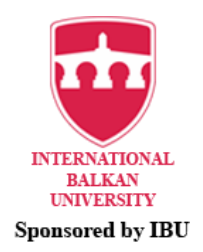

Sponsored by IBU

\title{
Gazete Haberlerinde Eğitim Yöneticisi
}

Education Administrators in Newspapers

\author{
Yasemin Fatma Tekin* - Bertan Akyol**
}

\begin{abstract}
The purpose of this study is to examine the news about education administrators in the print media between 1st September and 31st December 2017 in the daily press. The sample of the study is a newspaper with the highest circulation in the mass media. In this research that was designed as a qualitative study document analysis method was used and the data were analysed with content analysis technique. The data of the research were analysed under positive reflection of the educational administrations and negative themes, which are reflected in the newspaper about education administrators. 46 of 65 newspaper news stories about education administrators are positive and 19 are negative news. According to the research data, the majority of the positive news reflected to the print media about education administrators are the news of educational projects. Positive news focus on supervision, meeting, implementation of projects, school safety, school development, and social activity. Negative news focus on violence, sexual abuse, punishment, mobbing and complaints. This study shows that all the studies on behalf of education in which education administrators are involved are reflected in the newspapers as positive news. It can be said that the negative news reflected in the newspapers about educational administrators are sexual abuse, harassment, violence against students and teachers, and mobbing. As education administrators are exemplary to the society, the issues such as beating the student, insulting someone, labeling the student in some way and and punishing them in a way that does not comply with ethical behaviors are reflected to the press negatively.
\end{abstract}

Structured Abstract: Introduction: Today, the communication and broadcasting tools that are used to reach information are press, smart phones, computers, televisions and other technological vehicles. These tools called media and the power of the media that influence the masses cannot be denied. It can be said that the quality of the news in the media raises the public awareness, yet it misrepresents the public views. Considering the goals of the media influencing the society and reaching more people, it can be stated that the importance of quality in written and visual media news increases (Berkant, Cömert, 2013).

\footnotetext{
* Doktora Öğrencisi, Aydın Adnan Menderes Üniversitesi, Eğitim Fakültesi, Eğitim Bilimleri Bölümü, Eğitim Yönetimi Anabilim Dalı.

PhD Student, Aydin Adnan Menderes University, Faculty of Education, Department of Educational Sciences,

Educational Administration

ORCID 0000-0002-5937-7000

yaseminfatmatekin@hotmail.com

** Doç. Dr., Aydın Adnan Menderes Üniversitesi, Eğitim Fakültesi, Eğitim Bilimleri Bölümü, Eğitim Yönetimi Anabilim Dal1.

Assoc. Prof. Dr., Aydin Adnan Menderes University Faculty of Education, Department of Educational Sciences, Educational Administration

ORCID 0000-0002-1513-1885

bertanakyol@yahoo.com

Cite as/ Atıf: Tekin, Y. F. \& Akyol, B. (2020). Gazete haberlerinde eğitim yöneticisi. Turkish Studies - Education, 15(3), 2101-2115. https://dx.doi.org/10.29228/TurkishStudies.41971

Received/Geliş: 01 March/Mart 2020

Accepted/Kabul: 21 June/Haziran 2020

Checked by plagiarism software

Copyright (C) INTAC LTD, Turkey 
The General Directorate of Personnel of the Ministry of National Education has published the principles of professional ethics. School administrators should take the necessary precautions to ensure that education is carried out in a healthy and safe environment and that the resources of the institution are used effectively and efficiently. Another ethical behaviour expected from school administrators is not to discriminate among teachers, students and parents based on race, language, religion, colour, gender, political view and status. School administrators should provide teachers, students and parents opportunity to express the problems and to propose solutions. They should be in contact with parents regarding the education of students. In addition, school administrators are expected to comply with the principles of equality, impartiality and merit among teachers in provision of educational services (MEB, 2016).

\section{Purpose}

While education administration is accepted as a sub-branch of management science, education management process is defined as operating, developing and innovating educational organizations established to meet the educational needs of the society within the framework of predetermined objectives (Başaran, 1996). School administration, as a sub-area of education administration, is responsible for achieving specific and general objectives determined in line with state policies (Kaya, 1993). Therefore, education administrators are obliged to act in accordance with the laws, professional and social ethical principles while performing their duties. Ethical behaviours of the leader are truth, honesty, justice, tolerance, respect for values and rules, modesty, appreciation and reward. The purpose of this study is to reveal how the education administrators, who have the power to influence society so much, are reflected in the media.

\section{Method}

This research is a qualitative case study model. For the purpose of the study, criterion sampling method, one of the purposeful sampling methods, was used. Document analysis method was used in the research. In this study, the news of the education administrators who were reflected in the press in a certain period of time was investigated and their reflections to the press in their own context were described. The research can be evaluated as an empirical research (Yin, 2009) that deals with a current phenomenon in its environment. In the case study, the subject under study is described depending on its context and it is limited (Creswell, 2013). Documents used in this research are newspapers that are popular culture papers. For data analysis, descriptive content analysis techniques were used.

\section{Findings}

Data analysis of the study revealed that 46 of 65 newspaper news stories about education administrators are positive and 19 are negative news. According to the research data, the majority of the positive news reflected to the print media about education administrators are the news of educational projects. Positive news focus on supervision, meeting, project implementation, school safety, school development, and social activity. Negative news focus on violence, sexual abuse, punishment, mobbing and complaints.

\section{Discussion \& Conclusion}

As a result of this study conducted on the basis of newspaper reports related to education administrators between 1st September and 31st December 2017, 46 of 65 newspaper articles were positive and 19 of them were negative. 25 positive news and four negative news were found about the provincial and district national education administrators in the four-month period. In the same four-month period, 21 positive and 15 negative news were found regarding school administrators. This study was based on newspaper reports and included only cases with the highest circulation in the newspaper and published in the four-month period. When the content of the news is considered, the fact that 46 of the 65 content is positive can be described as pleasing on behalf of education administrators.

Keywords: Educational Admisitration, Education Administrator, News Reports, Ethical Behavior, Ethics in Education.

Öz: Bu çalışmanın amacı, kamuda görevli eğitim yöneticilerine ilişkin 1 Eylül-31 Aralık 2017 tarihleri arasında gazetelere yansıyan haberlerin incelenmesidir. Araştırmanın örneklemini kitle iletişim araçlarından olan tirajı en yüksek bir gazete oluşturmaktadır. Nitel durum çalışması deseninde olan bu araştırmada doküman analizi yöntemi kullanılmış, elde edilen veriler betimsel analiz ve içerik analizi tekniği ile çözümlenmiştir. 
Araştırmanın verileri, eğitim yöneticileri ile ilgili gazetelere yansıyan "olumlu” ve "olumsuz" olmak üzere iki ana tema altında çözümlenmiştir. Eğitim yöneticileri ile ilgili 65 gazete haberinin 46'sı olumlu, 19'i olumsuz haberdir. Araştırma verilerine göre eğitim yöneticilerine ilişkin gazetelere yansıyan olumlu haberlerin büyük çoğunluğunu eğitim amaçlı yürütülen projelerin haberleri oluşturmaktadır. Olumlu haberler denetim, eğitim toplantısı, projelerin hayata geçirilmesi, okul güvenliği, okulu iyileştirme, sosyal faaliyet konularında yoğunlaşmaktadır. Olumsuz haberler ise şiddet, cinsel istismar, ceza, mobbing ve şikâyet konularında yoğunlaşmaktadır. Bu çalışma, eğitim yöneticilerinin dâhil olduğu ve eğitim adına yapılan tüm çalışmaların gazetelere olumlu haber olarak yansıdığını göstermektedir. Eğitim yöneticileri ile ilgili gazetelere yansıyan olumsuz haberlerin toplumda da infial yaratacak olan cinsel istismar, taciz, öğrenciye ve öğretmene şiddet ve mobbing haberleri olduğu söylenebilir. Eğitim yöneticileri topluma örnek teşkil etmeleri sebebiyle yöneticilerle ilgili olarak öğrenciyi dövme, herhangi birine hakaret etme, öğrenciyi bir şekilde etiketleme ve etik davranışlara uymayacak şekilde cezalandırma basına olumsuz olarak yansımaktadır.

Anahtar Kelimeler: Eğitim Yönetimi, Eğitim Yöneticisi, Gazete Haberleri, Etik Davranış, Eğitimde Etik.

\section{Giriş}

Yazılı basında eğitime ilişkin haberlere sıkça rastlanmakta ve gün geçtikçe bu haberler okuyucuların ilgisini daha fazla çekmektedir. Türk Dil Kurumu'na göre haber, bir olay, bir olgu üzerine edinilen bilgi, iletişim ve yayın organlarıyla verilen bilgi olarak tanımlanmaktadır (Türk Dil Kurumu, 2018). Günümüz toplumlarında bilgiye ulaşmak için kullanılan iletişim ve yayın organları ise yazılı basın, akıllı telefonlar, bilgisayarlar, televizyonlar ve diğer teknolojik araçlardır. Medya olarak adlandırılan bu araçlar ve bu araçların sunduğu ortamın kitleleri etkileme gücü yadsınamaz. Medyadaki haberlerin niteliğinin halkın bilinçlenmesini sağladığı gibi, bazı haberlerin bireyleri yanlış yönlendirdiği de söylenebilir. Medyanın toplumu etkileme ve daha çok insana ulaşabilme hedefleri düşünüldügünde, yazılı ve görsel medyada yer alan nitelikli haberlerin öneminin daha da arttırdığı ifade edilebilir (Berkant, Cömert, 2013).

Medyanın toplumsal gücünün sosyalizasyon sürecinde önemli bir etkisi olduğu belirtilebilir. Bu etkinin ise her zaman olumlu olduğu söylenilemez. Bu süreçte medya, çocukların yaşantısında ve kişiliklerinde derin izler bırakabilmekte, ayrıca genç-yetişkin bütün insanların yaşamları boyunca süren uzun dönem sosyalizasyonu üzerinde de sürekli bir etkiye sahip olabilmektedir (Arslan, 2004). Bununla birlikte eğitim ve eğitim sürecine ilişkin uygulamaların medyaya yansıması, hem eğitimin kalitesine etki edebilmekte hem de eğitimin tüm paydaşlarını karar noktasında yönlendirebilmektedir (Blackmore ve Thorpe, 2003; Blackmore ve Thomson, 2004). Çünkü eğitim bir toplumun sahip olduğu insanı yeniden yaratarak geleceğini kontrol etme girişimidir. Toplumlarda bu görevi üstlenen kurumlar ise okullardır. Okulların yönetimi ise eğitim yönetimi uzmanlığı olarak karşımıza çıkmaktadır. Eğitim yöneticilerinin bu bağlamda bir takım sorumlulukları bulunmaktadır. İnsanlarla etkili biçimde çalışma, etkili bir işletme yönetimi, okul binasının ve çevresinin hazırlanması, eğitim programının geliştirilmesi ve mesleğine hizmet etme eğitim yöneticisinin görevleri arasındadır (Aydin, 2013).

Eğitim yönetimi ise, yönetim biliminin alt dalı olarak kabul edilirken eğitim yönetimi süreci de toplumun eğitim ihtiyacının karşılamak üzere kurulan eğitim örgütlerinin daha önceden belirlenmiş amaçlar çerçevesinde işletmek, geliştirmek ve yenileştirmek olarak belirtilmektedir (Başaran, 1996). Okul yönetimi de eğitim yönetiminin bir alt alanı olarak, devlet politikalarının doğrultusunda belirlenmiş özel ve genel amaçları gerçekleştirmekle sorumludurlar (Kaya, 1993). Bu nedenle bakanlık teşkilatından okullara kadar, tüm eğitim yöneticileri görevlerini yerine getirirken yasalara, mesleki ve toplumsal etik ilkelerine uygun olarak davranmakla yükümlüdürler. Etik davranışlar sergileyen liderden izleyenler; doğruluk, dürüstlük, adalet, hoşgörü, değerlere ve kurallara sayg1; alçak gönüllülük, takdir etme ve ödüllendirme; toplumsal sorunlara karşı duyarlılık, liyakate önem verme gibi etik değerler göstermesini beklemektedirler. Etik değerlerin liderlikteki önemi insanlık tarihinin birçok döneminde ifade edilmiştir. Yusuf Has Hacib, 1069 ve 1070 
yıllarında yazdığı Kutadgu Bilig adlı eserinde doğru sözlü, dürüst, seçkin ve iyi huylu, adil, hayâ ve takva sahibi, alçak gönüllü, cesaretli, sabır ve sükûnetli, 1lımlı ve cömert olmak, fesat ve kötü alışkanlıklar sahibi olmamak, doğru kuralları koymak ve zulmetmemek, hizmette bulunanları ödüllendirmek gibi etik değerlerin liderde bulunması gerektiğini dile getirmiştir (Aktan, 1999: 99; akt: Y1lmaz, 2006).

Eğitim öğretim hizmeti verenler için, Milli Eğitim Bakanlığı Personel Genel Müdürlüğü mesleki etik ilkelerini belirleyerek yayınlamıştır. Okul yöneticileri, eğitim ve öğretimin sağlıklı ve güvenli bir ortamda yapılabilmesi için gerekli önlemleri almalı, kurum kaynaklarının etkin ve verimli bir şekilde kullanılmasını sağlamalıdırlar. Okul yöneticilerinden beklenen bir diğer etik davranış biçimi ise öğretmenler, öğrenciler ve veliler arasında ırk, dil, din, renk, cinsiyet, siyasi görüş ve aile statüsüne dayalı ayrımcılık yapmamalarıdır. Okul yöneticileri, öğretmenlere, öğrencilere ve velilere okulda yaşanan sorunları ifade edebilme ve çözüm önerisi sunabilmeleri için firsat vermelidirler. Öğrencilerin eğitim ve öğretimi ile ilgili olarak velilerle iletişim içinde olmalıdırlar. Ayrıca okul yöneticilerinden eğitim hizmetlerinin yürütülmesinde öğretmenler arasında eşitlik, tarafsızlık ve liyakat ilkelerine riayet etmeleri beklenmektedir (MEB, 2016). Bu ilkelere öğretmenlerin, okul yöneticilerinin, il ve ilçede müdürlüklerinde yönetici olarak görev alan tüm personelin uyması ve olumlu davranışlar sergilemesi toplum tarafından beklenmektedir.

Türk Dil Kurumuna göre "olumlu”, gözetilen amaca veya beklenilene uygun, yararl,, müspet, pozitif, yapıcı, davranışları beğenilen, yapıcı düşünceleri olan olarak tanımlanmaktadır. Olumsuz ise, yapıcı ve yararlı olmayan, hiçbir sonuca ulaşmayan, gözetilen amaca veya beklenilene uygun olmayan, menfi, negatif, davranışları beğenilmeyen, yıkıcı düşünceleri olan, zararlı, menfi olarak ifade edilmektedir. Bu bağlamda toplumu bu denli etkileme gücü olan eğitim yöneticilerinin yazılı basına nasıl yansıdıklarının ortaya çıkarılması bu araştırmanın amacıdır. Bu amaca ilişkin şu alt problemlere yanıt aranmıştır:

1. Eğitim yöneticileri ile ilgili haberlerin gazetelere olumlu yansımaları nasıldır?

2. Eğitim yöneticileri ile ilgili haberlerin gazetelere olumsuz yansımaları nasıldır?

\section{Yöntem}

\section{Araştırmanın Modeli}

$\mathrm{Bu}$ araştırma nitel bir durum çalışması modelindedir. Nitel araştırmalar belirlenen konuyu derinlemesine araştırmayı amaçlamaktadır. Durum çalışması ise geçmişte ya da halen var olan bir olayın, durumun, birbirine bağlı sistemlerin, programın ya da sosyal bir grubun var olduğu şekliyle tespit edilerek derinlemesine araştııılmasının amaçlandığı bir modeldir (McMillan, 2000). Araştırma, güncel bir olguyu, bulunduğu çevre içerisinde ele alan bir araştırma (Yin, 2009) olarak değerlendirilebileceği için de bütüncül tek durum desenindedir. Durum çalışmasında, araştırılan konu içinde bulunduğu zamana bağlı olarak betimlenerek sınırlandırılmaktadır (Creswell, 2013). Bu çalışmada da belirli bir zaman diliminde yazılı basına yansımış olan eğitim yöneticilerinin haberleri araştırılarak, kendi bağlamlarında basına yansımaları resmedilmeye çalışılmıştır.

\section{Çalışma Materyali}

Araştırmanın amacı doğrultusunda, amaçlı örnekleme yöntemlerinden ölçüt örnekleme yöntemi kullanılmıştır. Ölçüt örnekleme yöntemindeki temel anlayış önceden belirlenmiş bir dizi ölçütü karşılayan bütün durumların çalışılmasıdır (Yıldırım ve Şimşek, 2013). Bu çalışmada sözü edilen ölçütlerden birincisi 2017 yılında ulusal basında Eylül, Ekim, Kasım ve Aralık ayları arasında Türkiye'de tirajı en yüksek gazetede çıkan eğitim yöneticileri ile ilgili haberlerdir. Bu ölçüte göre ulusal basında 1 Eylül 2017 - 31 Aralık 2017 tarihleri arasında bir gazetenin ortalama 311.000 tiraj ile en yüksek rakama sahip olduğu belirlenmiştir (Gazetetirajları, 2017; Medyatava, 2017). Diğer ölçüt ise araştırmanın sınırlılığından dolayı sadece bir eğitim ve öğretim döneminin 
değerlendirilmesidir. $\mathrm{Bu}$ bağlamda yayınlanan eğitim yöneticileri ile ilgili haberler durum çalışmasının amacına uygun olarak belirli bir zaman dilimi ile sınırlandırılmış (Creswell, 2013) ve incelenmiştir. Bu tarihler arasında belirlenmiş gazetede yayınlanmış eğitim ile ilgili toplam 334 habere ulaşılmış ve içlerinden eğitim yöneticilerinin öznesi ve nesnesi olduğu 65 tane gazete haberi veri toplama aracı olarak seçilmiştir.

\section{Veri Toplama Aracı ve Süreci}

Araştırmada doküman incelemesi yöntemi kullanılmıştır. Doküman inceleme, araştırılması istenen olgu veya olaylar hakkında bilgi içeren yazılı materyallerin analizini kapsamaktadır (Yıldırım ve Şimşek, 2013). Bu araştırmada kullanılan dokümanlar ise popüler kültür evraklarından olan gazetelerdir (Merriam, 2015). Bu araştırmanın verileri 1 Eylül 2017 ve 31 Aralık 2017 tarihleri arasında Türkiye genelinde tirajı en yüksek bir gazetede yayınlanmış olan eğitim haberleri kategorisindeki eğitim yöneticileri ile ilgili haberler, doküman incelemesi yoluyla incelenerek elde edilmiştir.

İşlem: Eğitim yöneticileri ile ilgili haberlerin analizi için tirajı en yüksek gazete belirlenmiş ve ölçüt örneklemeye uyan tüm eğitim haberleri dijital ortamda kaydedilmiştir. Eğitim kategorisindeki haberlerin içeriği tek tek incelenmiş ve eğitim yöneticilerinin haberin öznesi ve nesnesi olduğu 65 habere ulaşılmıştır. Eğitim yöneticileri ile ilgili haberler numaralandırılarak sıraya konulmuştur. Belge haline getirilen haberler ile 60 sayfalık veri oluşturulmuş ve çıktı olarak alınmışır.

\section{Verilerin Analizi}

Verilerin analizinde iki analiz tekniği kullanılmıştır. Eğitim yöneticileri ile ilgili gazete haberleri araştırmanın alt problemlerine uygun olarak olumlu ve olumsuz olarak temalandırılmış, ardından bu temalara ait haberler içerik analizi tekniği ile kategorilere ayrılarak çözümlenmiştir. İçerik analizinin temel amacı toplanan verileri açıklayabilecek kavramlara ve ilişkilere ulaşmak, birbirine benzeyen verileri belirli kavramlar ve temalar çerçevesinde bir araya getirmek ve bunları okuyucunun anlayabileceği biçimde yorumlamaktır (Yıldırım ve Şimşek, 2013). Mevcut metinlerden hareketle sosyal gerçeğe yönelik önermeler elde etmeyi amaçlayan içerik analizi ile sayıca fazla olan metinler arasında, araştırma sorusu açısından önem teşkil eden ortak bilgiler tespit edilmekte ve değerlendirilmektedir. $\mathrm{Bu}$ yönüyle içerik analizi, araştırılan metinlerin içeriklerinin tümüyle ilgilenmemekte, araştırma açısından önem arz eden boyutu üzerinde odaklanmaktadır. Diğer bir deyişle içerik analizi, araştırma sorusu doğrultusunda, metinlerin içeriklerinden önem arz eden bilgileri seçmekte, sınıflandırmakta ve yorumlamaktadır (Gökçe, 2006).

Haberler analiz edilmeden önce iki kez okunmuş, nitel araştırmanın temel mantığı olan verilerle uzun süreli etkileşimin sağlanması için de analiz sürecinde her haber tekrar gözden geçirilmiştir. Gazete haberlerine dayalı olarak içerik analizinden önce olumlu ve olumsuz haber temaları oluşturulmuş ve haber içerikleri bu temalar altında kategorilere ayrılmıştır. Haber içerikleri iki araştırmacı tarafından ayrı ayrı kategorilere ayrılmış ve \% 85 uyumlu olan kategoriler altında veriler çözümlenmiştir. Bulgular kısmında haber içerikleri temalar ve kategoriler altında çözümlenip yorumlanırken direkt alıntılara yer verilmiştir. Haberler her ne kadar daha önce gazetelerde yayınlanmış olsada, bulgularda haber içeriklerine yer verilirken okul ve kişi isimlerine yer verilmemiş ya da farklı isimler kullanılmıştır.

\section{Bulgular}

Araştırmanın bu bölümünde 2017 yılı Eylül, Ekim, Kasım ve Aralık aylarında eğitim yöneticileri ile ilgili olarak basına yansıyan olumlu ve olumsuz haberlerin neler olduğuna yer verilmektedir. İlk olarak Tablo 1'de eğitim yöneticilerinin aylara göre haber dağılımları verilmiştir: 
Tablo 1: Eğitim Yöneticileri ile İlgili Olumlu ve Olumsuz Haberlerin

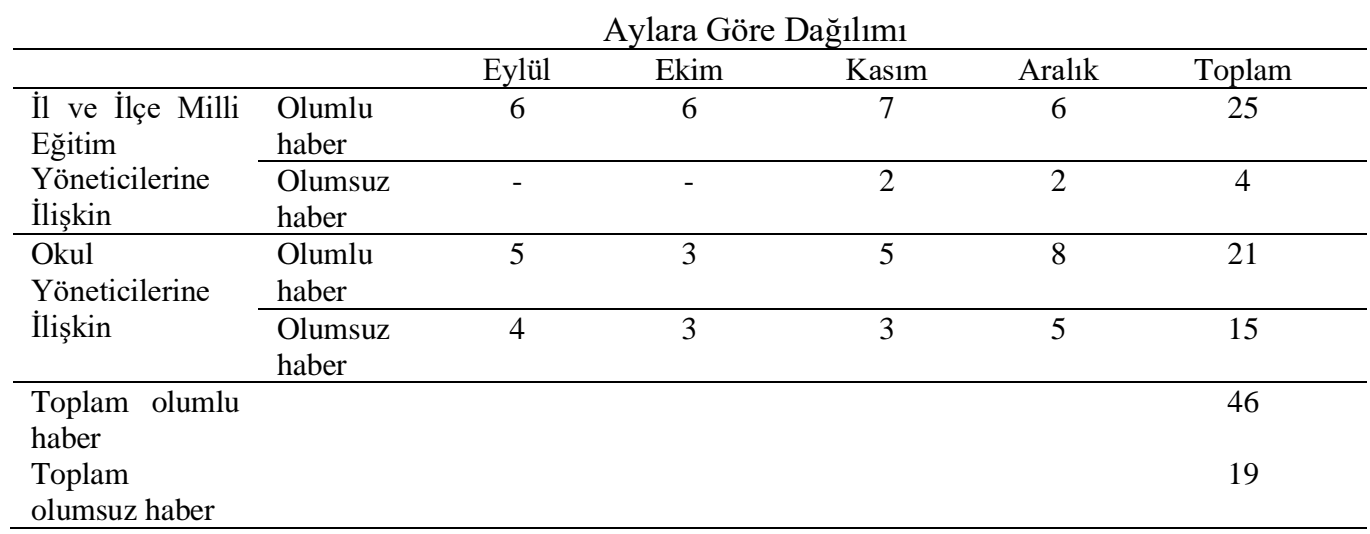

Tablo 1'de görüldügü gibi il ve ilçe milli eğitim yöneticileri ile ilgili olarak 2017 y1lı Eylül, Ekim, Kasım ve Aralık aylarında toplamda 29 haber basına yansımıştır. Basına yansıyan bu haberlerin 25'i olumlu 4'ü olumsuz haber olarak belirlenmiştir. Okul yöneticileri ile ilgili basına yansiyan haberlerin toplam sayıs1 36 iken bu sayının 21'ini olumlu 15'ini olumsuz haberler oluşturmaktadır. 2017 Eylül, Ekim Kasım ve Aralık aylarının toplamına bakıldığında ise eğitim yöneticileri ile ilgili basına yansıyan haberlerin \% 70'i olumlu, \%30'u olumsuz olarak değerlendirilebilir.

2017 yılı Eylül, Ekim, Kasım ve Aralık aylarında eğitim yöneticileri ile ilgili olarak basına yansıyan olumlu haberlerin içerikleri ise Tablo 2'de verilmiştir:

Tablo 2: Eğitim Yöneticileri ile İlgili Basına Yansıyan Olumlu Haberler Temas1

\begin{tabular}{|c|c|}
\hline Olumlu Haberler Temasına Ait Kategoriler & $\mathbf{f}$ \\
\hline Proje haberleri kategorisi & 8 \\
\hline 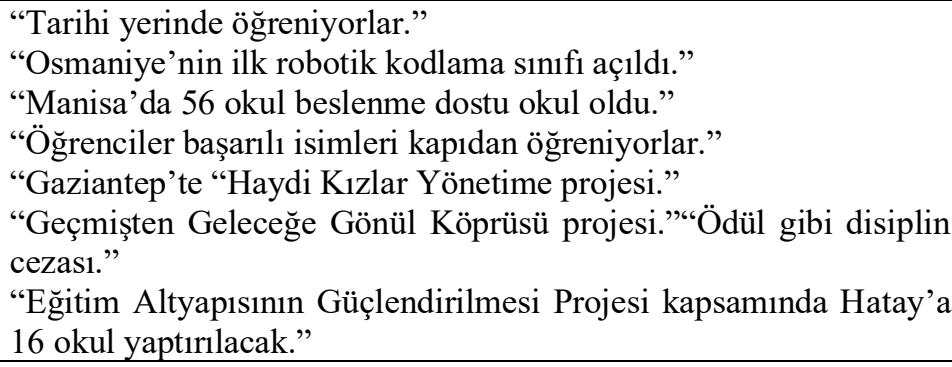 & \\
\hline Toplantı haberleri kategorisi & 7 \\
\hline $\begin{array}{l}\text { "Yalova'da lise müdürleri ile toplantı yapıldı." } \\
\text { "Okul-sanayi işbirliği toplantısı." } \\
\text { "Müdür Akpınar, okul müdürlerinin katılımı ile toplantı } \\
\text { düzenlendi." } \\
\text { "Yalova'da eğitim kurumlarının müdürleri eğitimde niteliği arttırma } \\
\text { toplantısı yaptı." } \\
\text { "Mersin'in eğitim durumu tartışıldı." } \\
\text { "Kırklareli'nde eğitim konulu toplantıda sorunlar dinlendi." } \\
\text { "Eğitimcilere uyuşturucu ile mücadele semineri." }\end{array}$ & \\
\hline Eğitim-öğretim sürecine ilișkin haberler kategorisi & 6 \\
\hline
\end{tabular}




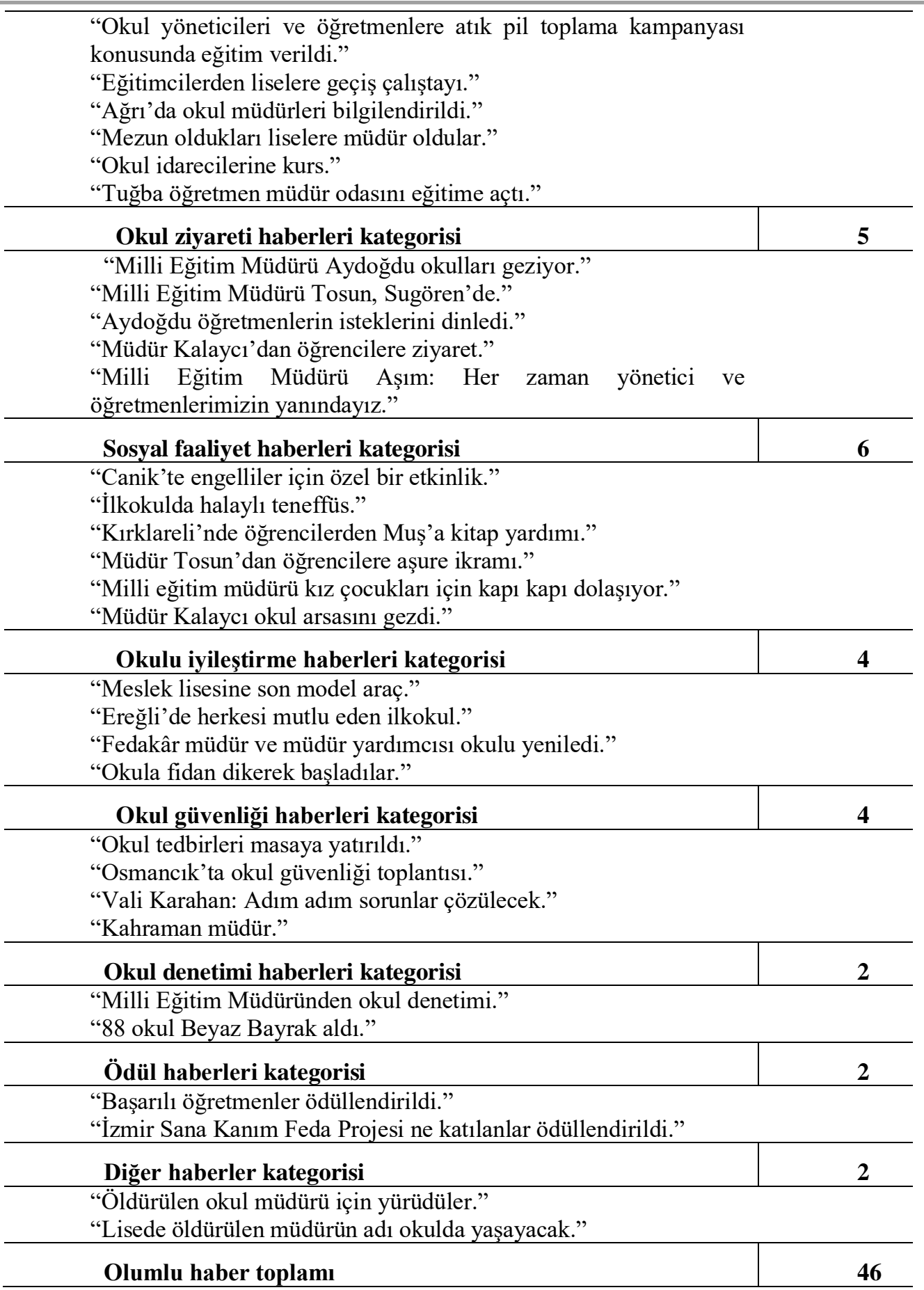

Tablo 2' de görüldüğg̈ gibi, okul yöneticileri ile ilgili olarak 46 haber gazeteye olumlu olarak yansımıştır. Olumlu haberler teması incelendiğinde proje, toplantı, eğitim öğretim sürecine ilişkin haberler, okul ziyareti, sosyal faaliyet, okulu iyileştirme, okul güvenliği, okul denetimi, ödül ve diğer haberler olarak alt temalara ayrılabilir. Proje haberleri içerisinde geleceği kodluyoruz projesi altında gerçekleştirilen robotik kodlama sınıfının açılması ile Osmaniye'de bir lisenin müdürü öğrencileri yarına göre yetiştireceklerini belirtmiştir. Tarihi yerlerinde öğreniyorlar haberinde, okul müdürü proje sayesinde Kilis'deki bir lisenin öğrencilerinin tarih derslerini kentin tarihe 1şık tutan mekânlarında işlemeye başlandığını belirtmiştir. Manisa'da 56 okulun beslenme dostu olduğu 
haberde, il milli eğitim müdür yardmımcısı beslenmenin önemine değindikten sonra, il sağlık müdür yardımcısı ile birlikte okulların sertifikalarını dağıttığı belirtilmiştir. Gaziantep Büyükşehir Belediyesi ve il milli eğitim müdürlügünce ortaklaşa yürütülen 'Haydi Kızlar Yönetime' projesi kapsamında Başkan Fatma Şahin, bölgedeki bir okula devam eden 162 kız öğrenciyi ağırlamış, kız öğrencilere tecrübesini aktarıp, soruları yanıtlamıştır.

Ödül gibi ceza haberinde ise Batman'daki bir lisenini müdür yardımcısı "disiplin suçu işleyen ögrencilere, kitap okuma cezası veriliyor. Uygulama ögrencilerin kitap okuma oranını artırırken, okul içerisindeki olayları azaltıyor" diye belirtmiştir. Yalova İl Milli Eğitim müdürü "Geçmişten Geleceğe Gönül Köprüsü Projesi” kapsamında 2017-2018 eğitim-öğretim yılında "Eğitimde Motivasyonu Arttırmak ve Kaliteyi Yükseltmek" amacı ile rehber öğretmenler, din kültürü ve ahlak bilgisi öğretmenleri, meslek dersi ve kültür dersi öğretmenleriyle ayrı ayrı toplantılar düzenleyerek, istişarelerde bulunduklarını belirtmiştir. Emekli öğretmenlerle buluşarak tecrübelerle eğitimde başarıya ivme kazandırmaya çalıştıklarını söylemiştir.

Olumlu haber kategorisinde bulunan proje haberlerinden en dikkat çekicilerinden birinin "Öğrenciler başarılı isimleri kapıdan öğreniyorlar" projesidir. Samsun'daki bir imam hatip ortaokulunda başlatılan "Sınıf Kapısı Giydirme Projesi" sayesinde öğrencilerin, başarı sağlamış kişileri tanıma firsatı yakaladığı belirtilmiştir. Amaçlarının spor, ekonomi, akademik ve uluslararası alanlarda başarı sağlamış insanları öğrencilere tanıtmak olduğunu söyleyen okul müdürü, "Öğrencilerimize kendi tarihimizde ve günümüzde başarı sağlamış şahsiyetleri tanıtma amaçlı 'Sınıf Kapısı Giydirme Projesi'yaptı. Bizim bu projede amacımız spor, ekonomi, akademik ve uluslararası alanlarda başarı sağlamış kendi insanımızı çocuklara tanıtmak" diyerek hem velilerin hem de öğrencilerin projeye ilgisini belirtmiştir. Avrupa Birliği'nden sağlanan kaynakla, 'Eğitim Altyapısının Güçlendirilmesi Projesi' kapsamında Hatay'a 16 okul yaptırılacağı da bu kategorideki haber içeriklerinde belirtilmiştir.

Olumlu haberlerden toplantı içerikli haberler kategorisi incelendiğinde ise eğitim yöneticilerinin genellikle toplantılarda sorunları dinleme, tartışma, yapılacak faaliyetler, öğrencilerin başarılarının geliştirilmesi için yürütülen çalışmalar, okul rehberlik hizmetleri, okullardaki kültürel, sanatsal ve sportif faaliyetler, okul güvenliği, kurum standartları çalışmalarına ilişkin gündem maddeleri üzerinde durdukları görülmüştür. Toplantı haberlerinden Afyonkarahisar'ın bir ilçesindeki okul-sanayi işbirliği toplantısında meslek liselerin önemi yerel yöneticiler tarafından,

"...her çocuk okuyup kaymakam, doktor, mühendis olmuyor. Bu bölümlere bu kadar elamana da zaten ihtiyaç yok. Bu anlamda diğer mesleklere de elemana ihtiyacımız var. Ayrıca bu mesleklerden de çok iyi paralar da kazanıla biliniyor. Sanayimizin gelişmesi, kalkınmamız ve üretim yapmamız için zanaat ve mesleklerin önemi büyük. Biz de yanlış bir algı var. Bizim çocuk okuyacak büyük adam olacak. Mesleğin kötüsü yok. Önemli olan iyi meslek sahibi olsun. Büyük adamın ölçüsü memlekete faydalı meslek sahibi olan adam olsa gerek"

sözleri ile belirtilmiştir.

Medyaya yansıyan olumlu haber kategorisine giren eğitim haberlerinde okul yöneticileri ve öğretmenlere atık pil toplama kampanyası konusunda verilen eğitim, eğitimcilerden liselere geçiş çalıştayı, Ağrı'da okul müdürlerinin yeni müfredat konusunda bilgilendirilmeleri, okul idarecilerine verilen soruşturma teknikleri kursu bulunmaktadır. Bu kategoride Muş merkeze bağlı bir köyde iki yıldan beri okul müdürlüğü yapan bir kadın sınıf öğretmeninin, okuldaki makam odasından depoya kadar her tarafı öğrencilerin eğitimine açtığı haberi ilgi çekicidir. Okul müdürü makam odasında sadece bilgisayarı kullanırken, odasının bir köşesini kitaplık, bir köşesini satranç ve oyun alanı yapıp, masasını da öğrencilerin çalışma alanına çevirdiği haberi göze çarpmıştır. "Mezun oldukları liselere müdür oldular" haberinde ise İzmir' in bir ilçesinde mezun oldukları liselere yıllar sonra müdür olarak atanan 3 eğitimcinin, hayallerini gerçekleştirmelerinin mutluluğunu yaşadıkları belirtilmiştir. 
Okul ziyareti haberleri ile ilgili haber kategorisinde bulunan haberlerin içerikleri ise eil ve ilçe düzeyinde görevli eğitim yöneticilerinin okulları gezmesi, öğretmenlerin isteklerini dinlmeleri, öğrencileri ziyaret etmeleri ve okul yöneticileri ve öğretmenlerin yanında olduklarını ifade eden haberler olumlu haberler olarak karşımıza çıkmaktadır.

Sosyal faaliyet haberleri içerisinde engelliler için düzenlenen özel doğum günü etkinliği okul yöneticisini medyaya olumlu yansitan haberlerdendir. Bu kategoride bulunan ve eğitim yöneticilerini olumlu yansitan haberlerden ilkokulda halaylı teneffüs haberi ilgi çekicidir. Erzurum'un bir ilçesindeki ilkokul yönetiminin soğuk havalarda öğrencilerin teneffüslerde bahçeye çıkıp hasta olmalarını engellemek için 'halaylı' çözüm bulmaları bu kategoride yer almaktadır. Kırklareli'nde öğrencilerden Muş'a kitap yardımı ve Yalova'da Muharrem ayı nedeniyle bir ortaokulda hazırlanan aşure dağıtım programı okul bahçesinde il milli eğitim müdürü tarafindan gerçekleştirilmiştir. Okulda gerçekleştirilen aşure günü ve "Kur'an'la Buluşma Projesi”, il milli eğitim müdürü, il milli eğitim müdür yardımcıları, kurum müdürleri, öğretmen, öğrenci ve velilerin katılımıyla gerçekleştirilmiştir.

Okulu iyileştirme haberleri kategorisindeki haberler incelendiğinde meslek lisesine öğrencilerin eğitimi ve yeni teknolojileri tanımaları için alınan son model araç haberi, öğrencilerin daha iyi şartlarda eğitim görmesi için düzenlenen ilkokul, fedakâr müdür ve müdür yardımcısının bizzat kendilerinin okulu yenilemeleri ve okula başlayan öğrencilerin okula fidan dikmeleri de eğitim yöneticilerinin içinde bulunduğu olumlu haberler arasındadır.

Son dönemde gündemde olan okul güvenliği, bu çalışmada olumlu haberler kategorisinde yer almıştır. Tokat il milli eğitim müdürlügünün okullarda güvenlik amacı ile alınan tedbirler, Çorum'un bir ilçesinde 2017-2018 eğitim öğretim yılının huzur ve güven içinde geçirilmesi amac1 ile yapılan okul güvenliği toplantısı, Denizli’de yine 2017-2018 eğitim öğretim yılı okul güvenliği toplantısı bu haberler içinde yer almıştır. Okul güvenliği kategorisindeki en ilginç haberlerden birisi ise Ankara'da bir ilkokulda çıkan yangını fark eden okul müdürünün itfaiye gelmeden öğrencileri tahliye ederek, yangın hortumu ile yangını kontrol altına alması olmuştur. Bu haber "Kahraman Müdür" başlığı ile verilmiştir.

Okul denetimi kategorisinde bulunan olumlu haber içeriklerine bakıldığında Mersin'in bir ilçesinin ilçe milli eğitim müdürünün okulları ziyaret etmesi ile ilgili haber ve Kayseri'deki 88 okulun hijyen açısından yeterli görülerek vali tarafindan okula beyaz bayrak verilmesi haberi yer almıştır.

Olumlu haberler kategorisindeki ödül haberlerinde Osmaniye'de "Eğitimde İyi Örnekler Osmaniye 2017" projesinde başarılı olan öğretmenlere ödül verildiği belirtilmiştir. Haberin içeriğinde il milli eğitim müdürü, çocukların eğitimine farklı bir şekilde yaklaşan, kalıcı öğrenmeyi gerçekleştirmeye çalışan öğretmenleri belirlemek için böyle bir çalışma yapıldığını belirtmiştir. Haberde en çarpıcı unsur Osmaniye valisinin öğrenme sürecinin etkili ve kalıcı olabilmesi için geleneksel yöntemlerin yanında ilgi çekici farklı öğrenme yöntemlerinin kullanılmasının gerektiğini belirtmesi olmuştur. Bu amaçla yapılan proje sonucunda 86 öğretmene ödül verilmiştir. Ödül haberleri kategorisindeki diğer haber ise İzmir İl Milli Eğitim Müdürlügünün Türk Kızılay’ı Ege Bölge Kan Merkezi ile gerçekleștirdiği "İzmir Sana Kanım Feda” kan bağışı kampanyasında İl Milli Eğitim Müdürünün bağışa katılan ve en çok bağış yapan okullara bisiklet hediye etmesi haberi bulunmaktadır.

İzmir'in bir ilçesindeki lise müdürünün öğrencisi tarafından pompalı tüfek ile vurularak öldürülmesi üzerine geniş katılımlı bir yürüyüş ve basın açılaması gerçekleştirilmiştir. Yürüyüşe ölen okul müdürünün eşi, çocukları ve yaklaşı üç bin kişi katılmıştır. Bu esnada kaymakamlık kararı ile eğitime iki gün ara verilmiş ve cinayet olayı öğretmenler, öğrenciler ve veliler tarafından kınanmıştır. Bir cinayet haberinin devamı olmasına rağmen, olumlu haberler kategorisinde yer alan 
haber öldürülen müdürün adının, bir okula verilecek olması "lisede öldürülen müdürün adı okulda yaşayacak" başlı̆̆ ile verilmiştir.

2017 yılı Eylül, Ekim, Kasım ve Aralık aylarında eğitim yöneticileri ile ilgili olarak basına yansıyan olumsuz haberlerin içerikleri Tablo 3'de verilmiştir:

Tablo 3: Eğitim Yöneticileri ile İlgili Basına Yansıyan

\begin{tabular}{|c|c|}
\hline Olumsuz Haberler Temasına Ait Kategoriler & $\mathbf{f}$ \\
\hline Cinsel istismar, taciz, şiddet ve mobbing haberleri kategorisi & 5 \\
\hline \multicolumn{2}{|l|}{$\begin{array}{l}\text { “... skandal! Müdür yardımcısı öğrencilere cinsel istismardan } \\
\text { tutuklandı.” } \\
\text { "Okul müdürüne cinsel istismar suçlaması ile } 44 \text { yıl hapis } \\
\text { istemi." } \\
\text { "'Okul müdürü öğretmene kâbusu yaşattı... İşte karar!” } \\
\text { " 'Müdür mobbing uyguluyor' dedi, hakkında soruşturma açıldı, } \\
\text { tayin edildi.” } \\
\text { "S'ınıfta dehşet dakikaları! O öğretmen için flaş karar." }\end{array}$} \\
\hline Ceza ve soruşturma haberleri kategorisi & 4 \\
\hline \multicolumn{2}{|l|}{$\begin{array}{l}\text { "Okul müdürü ceza kesen müdürle tartıştı, Cumhurbaşkanına } \\
\text { hakaretten gözaltına alındı." } \\
\text { "Sizinle kim baş edecek müdür bey!" } \\
\text { "Öğrencisini dövdüğ̈ iddia edilen müdür yardımcısı hakkında } \\
\text { soruşturma." } \\
\text { "Öğrenciyi hırsız diye teşhir eden okul müdürüne soruşturma." }\end{array}$} \\
\hline Cinayet haberleri kategorisi & 3 \\
\hline \multicolumn{2}{|l|}{$\begin{array}{l}\text { "Lise müdürü pompalı tüfekli saldırıda öldü." } \\
\text { "Okulda öldürülen müdüre otopsi yapıldı." } \\
\text { "Okul müdürünü öldüren öğrencinin babası: Oğluma değil, okul } \\
\text { müdürüne üzüldüm.” }\end{array}$} \\
\hline Diğer haberler kategorisi & 7 \\
\hline \multicolumn{2}{|l|}{$\begin{array}{l}\text { "Korkunç iddia: Müdür ve hizmetli açığa alındı.” } \\
\text { “Okul müdürü } 10 \text { Kasım’da şarkı eşliğinde oynadı iddiası.” } \\
\text { “... Milli Eğitim Müdürü’nden "Yapraklar İlkokulu” açıklaması" } \\
\text { "Bu müdür ne yapıyor?” } \\
\text { "Kanser hastası çocuğun fotoğrafını okula asıp teşhir ettiler } \\
\text { iddiası.” } \\
\text { "Müdüre bak! } 10 \text { yaşındaki öğrenciyi hırsız diye arkadaşlarına } \\
\text { teşhir etti.” } \\
\text { “... öğrenci laptop hediyesini alırken, okul müdürü de intihara } \\
\text { kalkıştı.” }\end{array}$} \\
\hline Olumsuz haber toplamı & 19 \\
\hline
\end{tabular}

2017 yılı 01 Eylül-31 Aralık tarihleri arasında eğitim yöneticileri ile ilgili 19 olumsuz haber basına yansımıştır. Olumsuz haberler teması incelendiğinde ise cinsel istismar, taciz, şiddet ve mobbing haberleri, ceza ve soruşturma haberleri, cinayet haberleri ve diğer haberler kategorilerine ulaşılmıştır. Cinsel istismar, taciz, şiddet, mobbing haberleri kategorisindeki ilk haber "...'de skandal! Müdür yardımcısı ögrencilere istismardan tutuklandı" başlığ 1 ile verilmiştir. Haberde Marmara bölgesinde bir lisenin müdür yardımcısının okulda sekiz kız öğrenciye cinsel istismarda bulunduğu iddiası ile tutuklandığı belirtilmiştir. Cinsel istismar suçlaması ile öne çıkan Akdeniz 
bölgesinde bulunan bir ortaokul müdürüne 11 ve 12 yaşlarındaki iki kız öğrenciye nitelikli istismar iddiası ile 44 yıl hapis cezası istemi ile açılan dava olmuştur. 2014 yılında yaşanan olay, öğrencilerin korkmalarından dolayı anne babalarına anlatmamaları sebebi ile ancak 2016 yılında ortaya çıkabilmiştir. Dramatik bir şekilde ortaya çıkan haberde,

“... 2014 yılında bir ortaokulda müdür olarak görev yapan Y.A., o dönem 6'nc1 sınıf öğrencilerinden 11 yaşındaki H.Y.'ye odasında cinsel istismarda bulundu. H.Y., okuldan alınacağı ve okul müdürüyle karşı karşıya gelerek zarar görecekleri korkusuyla yaşadığı olayı anne ve babasına anlatamadı.Ertesi yıl okul müdürü Y.A.'nın bir gün derse gelerek kendisine bakması sonrası ağlamaya başlayan H.Y., yanındaki arkadaşı B.G.'nin sorması üzerine başından geçenleri anlattı. B.G., müdürün benzer olayları aynı yurtta kaldığı arkadașı D.Y.'ye de yaptığını, D.Y.'nin kendisine müdürden uzak durmasını söylediğini anlattı. H.Y. bunun ardından yaşadığı olayı müdür Y.A.'nın aynı okulda öğretmen olarak görev yapan akrabası E.A.'ya da söyledi. Bir süre sonra yaşadıklarının okulda duyulması üzerine psikolojisi bozulan H.Y., 2016 yazında yaşadıklarını annesi Z.Y.'ye anlattı.”

ifadeleri ile verilmiştir. Ardından olay adliyeye intikal etmiştir. Haberin ilginç olan yanı ise kız öğrencilerden bir tanesinin anne babasının dilekçe vererek şikâyetçi olmadıklarını beyan etmeleri olmuştur. Tutuksuz yargılanan okul müdürü görevinden uzaklaştırılarak rehberlik ve araştırma merkezine öğretmen olarak atanmıştır. Haberin diğer ilginç detayı ise şüphelinin yakınlarının şikâyet eden aileye baskı kurması, evlerine kadar gelmesi, sürekli telefon açması, dilekçeyi geri çekmelerini istemeleri olmuştur. Ege bölgesindeki bir ilçede öğretmene cinsel saldırıda bulunduğu iddiası ile yargılanan okul müdürüne 3 yıl 9 ay ceza verilmiştir. Haberin en dikkat çekici yanı ise sanık avukatının “...bu tür bir eyleme maruz kalan kişinin polis imdat hattını araması, feryat etmesi ya da eşine haber vermesi gerekir..." diyerek bu suçun işlendiğine dair kanıtların bulunmadığını söylemesidir. Mahkeme sanığın tutuklanmasına yer olmadığına karar vermiştir. Cinsel istismar, taciz ve mobbing haberleri kategorisindeki bir diğer haber ise, Ege bölgesinde bir sınıf öğretmeninin okul müdürü ile ilgili olarak il milli eğitim müdürlüğ̈̈, valilik ve savc1lığa suç duyurusunda bulunmas1 olmuştur. Okul müdürünün mobbing uyguladığı iddiasında bulunan öğretmene soruşturma açılmış ve iç Anadolu'da bir ile tayin edilmiştir. Bu kategorideki son haber ise Karadeniz bölgesinde bulunan bir ilçedeki lise öğretmeninin öğrenciye sınıfta şiddet uygulamasının görüntüleri sonrasında il milli eğitim müdürlüğünün öğretmeni okuldan uzaklaştırdığı haberidir.

Olumsuz haberler kategorisindeki ceza ve soruşturma haberlerine bakıldığında ilk haberin içeriği Ege bölgesinde bir imam hatip ortaokulunun müdürünün otomobili ile hız sınırını aşttğı gerekçesi ile kendisine ceza kesen trafik polisleri ile tartışmasıdır. Tartışma sırasında Cumhurbaşkanına hakaret ettiği öne sürülen okul müdürü ifadesinin ardından serbest bırakılmıştır. Ceza ve soruşturma haberleri kategorisindeki diğer haber ise Marmara bölgesinde bir ilçede bulunan ilkokul müdürünün hiper aktif bir çocuğu baș edemedikleri gerekçesi ile öğretmenler günü töreni boyunca beton zeminde oturtması olmuştur. Aynı haberde okul müdür ile ilgili olarak daha önce görev yaptığı okuldan yolun karşısında bulunan evine çektiği kalorifer hattı ile gündeme geldiği de belirtilmiştir. "Öğrencisini dövdüğ̈̈ iddia edilen müdür yardimcısı hakkinda soruşturma" başlıklı haber bir imam hatip ortaokulunda gerçekleşmiştir. Öğrenciyi dövdüğü iddia edilen okul yöneticisi ile ilgili velinin şikâyeti üzerine soruşturma başlatıldığı aktarılmıştır. Marmara bölgesindeki bir ilçe ilkokulunun müdürü ile ilgili olarak, okula ait dizüstü bilgisayarı oyun oynamak için eve götürdüğü gerekçesi ile on yaşındaki bir öğrenciyi tüm arkadaşlarının önünde hırsız olarak teşhir etmesinden dolayı soruşturma başlatılmıştır. Bilgisayarı oyun oynamak için götürdüğünü söyleyen öğrenci okula giriş töreninde hırsız olarak teşhir edilince gözyaşlarına boğulmuştur.

Olumsuz haberler kategorisindeki cinayet haberlerinin ilki ise Ege bölgesinde yer alan bir ilçedeki lise müdürünün öğrencisi tarafından pompalı tüfekle vurularak öldürülmesi haberidir. Cinayetin hemen ardından gözaltına alınan iki öğrenciden biri ile ilgili disiplin soruşturması yürütüldüğüu, diğerinin de okul müdürü tarafından sigara içtiği için uyarıldığı belirtilmiştir. Haberin 
devamı niteliğindeki diğer haberde ise okulda öldürülen müdüre otopsi yapıldığı belirtilmiştir. "Okul müdürünü öldüren ögrencinin babast: oğluma değil okul müdürüne üzüldüm” başlıklı haber de pompalı tüfekle öldürülen okul müdürünün cinayet haberinin devamı olup, müdürü öldüren iki öğrenciden birinin babasının oğluna en ağır cezanın verilmesini belirtmesi ve okul müdürüne üzüldüğünü söylemesidir.

Olumsuz haberler kategorisindeki diğer haberlerinin ilki Ege bölgesindeki bir ilçenin bir ilkokul ve ortaokulda hizmetli olan kişinin okul bahçesinde kaldığı lojmanda hem uyuşturucu kullandığı hem de ticaretini yaptığı iddiası ile milli eğitim müdürlüğünün soruşturma başlatarak hem okul müdürünü hem de hizmetliyi açığa aldığı haberidir. Diğer haber ise Akdeniz bölgesindeki bir lisede görev yapan okul müdürünün $10 \mathrm{Kasım}$ etkinliğinde çalınan şarkı eşliğinde oynadığı ileri sürülen görüntüler ile ilgili olarak soruşturma başlatılmasıdır. Okul müdürü ise görüntülerin 10 Kasımda değil 09 Kasım provalarında çalınan "sarı saçlı mavi gözlüm" şarkısı eşliğinde gerçekleştiğini söylemiştir. “... Milli Eğitim Müdürü’nden Yapraklar Illkokulu açıklaması” başlıklı haberde ise daha önce köye gelerek yardım dağıtan bir derneğin yanındaki basın mensuplarının Yanlızçamlar ilkokulu ile ilgili yaptıkları haberlerin gerçeği yansıtmadığının milli eğitim müdürü tarafından belirtilmesidir. Haberde okulun kötü durumda olduğu ve sobanın yanmadığı yayınlanmış, milli eğitim müdürü de bu haberde bütün bunları yalanlamıştır. Bu kategorideki en ilginç haber ise "bu müdür ne yapıyor?" başlıklı haberdir. Haberin içeriğinde ve fotoğraflarda Güneydoğu Anadolu bölgesindeki bir ilçede bulunan lise müdürünün bahçe kapısının önünde sandalyede oturarak içeri giren ögrencilere elini öptürmesi haberidir. Hem gazetede hem de sosyal medyada hızla yayılan habere kimse anlam verememiştir. "Kanser hastası çocuğun fotoğrafinı okula asıp teşhir ettiler iddiası" başlığı ile verilen haberde ise, kansere yenik düşen bir lise öğrencisinin eğitim gördüğü okulun yöneticilerinin öğrencinin devamsızlığı ile ilgili süreçte yaşananları bir açıklama haline getirip izinsiz olarak okulun çeşitli yerlerine asmaları nedeni ile öğrencinin babasının yöneticiler ile ilgili suç duyurusunda bulunacağı belirtilmiştir. Marmara bölgesinde bulunan bir okulda dizüstü bilgisayarın dördüncü sınıf öğrencisi tarafından götürüldüğünün tespit edilmesi üzerine okul müdürünün öğrenciyi törende teşhir etmesi bu okul müdürü için olumsuz nitelikte bir haber olarak karşımıza çıkmıştır.

\section{Tartışma, Sonuç ve Öneriler}

01 Eylül-31 Aralık 2017 tarihleri arasındaki eğitim yöneticileri ile ilgili gazete haberlerine dayalı olarak yapılan bu çalışma sonucunda, 65 gazete haberinin 46'sının olumlu, 19'unun olumsuz içerikte olduğu görülmüştür. İl ve ilçe milli eğitim yöneticilerine ilişkin dört aylık süreçte 25 olumlu habere, 4 olumsuz habere rastlanmıştır. Okul yöneticilerine ilişkin ise aynı dört aylık süreçte 21 olumlu, 15 olumsuz habere rastlanmıştır. Bu çalışma, gazete haberlerine dayalı olarak yapılmış ve çalışma kapsamına sadece tirajı en yüksek bir gazetedeki ve dört aylık süreçte yayınlanan haberlere yansıyan vakalar dâhil edilmiştir. Haber içeriklerine bakıldığında 65 içerikten 46 haberin olumlu olması eğitim yöneticileri adına sevindirici olarak nitelendirilebilir. Akbaba- Altun ve Kirkit (2005) okul yöneticilerinin basındaki imajını beş yıllık süre içinde üç farklı gazeteden araştırmışlar ve okul yöneticilerinin basına yansıyan konuların başında hukuksal konular gelirken, şiddet, ekonomik konular, kılık kıyafet ve övgü konuları bunu izlemiştir. Aynı araştırmanın sonucuna göre, okul yöneticilerinin basında olumsuz bir imaj çizdikleri belirtilmiştir.

Altun (2014), öğrenci, öğretmen ve idarecilere ilişkin haberleri incelemiş ve bu haberlerin büyük bir oranda (yaklaşı 3/4) olumsuz olduğunu belirtmiştir. Olumsuz örnekler daha çok adli vakalar ve gayri ahlaki konularla ilgiliyken; olumlu haberler de daha çok eğitime dair güncel ve ilginç haberleri oluşturmaktadır. Haber medyasının kamuoyunda öğrenci, öğretmen ve idareci konusunda oluşacak algıya pek de olumlu katkı sağlamadığı belirtilirken, bu noktada özellikle medya çalışanlarının haberlerin seçiminde ve sunumunda daha sorumlu hareket etmeleri gerektiği de ifade edilmiştir. 
Medyanın ve yazılı basının toplum üzerinde yadsınamaz bir etkisi olduğu bilinmektedir (Arslan, 2004). Gazetelere yansıyan eğitim haberleri toplumda eğitim kurumları ve eğitim yöneticileri ile ilgili yargıların oluşmasına neden olduğu gibi, eğitimde alınması gereken önlemler açısından da eğitim yöneticilerine yol göstermektedir. Gavish ve Oplatka (2012) Educational leadership in the era of mass media: state, consequences and repercussions (Kitle iletişim araçları döneminde eğitim liderliği: durum, sonuçları ve etkileri) isimli çalışmalarında bir yıl boyunca yazılı basında eğitimle ilgili kritik olayları incelemişlerdir. Hükümetin eğitim politikalarını teşvik etmek ve stratejik avantaj elde etmek için medyayı harekete geçirdiğini, bu süreç sonunda okulların ve öğretmenlerin etkilendiklerini, okulların ve sistem performansının medyadan, kamu algısından, okulların ve öğretmenlerin çalışmalarının topluluk anlayışından beslendiğini belirtmişlerdir.

Ülkemizde değerler eğitiminin merkezi bir rol oynadığı müfredat yenileme çalışmalarına ilişkin taslağın kamuoyu görüşüne sunulduğu dönem dikkate alınarak 1 Ocak 2017 ve 7 Mart 2017 tarihleri arasında ulusal gazetelerde yer alan değerler eğitimi konulu haberler sosyo/bilişsel yaklaşım çerçevesinde eleştirel söylem analizine dayalı olarak irdelenmiştir. Çalışmanın bulgularına göre gazetelerin değerler eğitimine oldukça sınırlı şekilde yer verdiği, değerler eğitiminin en azından incelenen dönem itibarı ile hak ettiği düzeyde ve eğitim bilimi bağlamında tutarlı bir biçimde ele alınmamış olduğu belirtilmiştir (Yaylacı ve Beldağ, 2018).

$\mathrm{Bu}$ çalışma, eğitim yöneticilerini dâhil olduğu ve eğitim adına yapılan tüm çalışmaların gazetelere olumlu haber olarak yansıdığını göstermektedir. Bu da eğitim öğretim sürecinin verimli olması için önem arz etmektedir. Aslında eğitim öğretim süreci ile direkt ilgili olan öğretmenlerin yaptığı proje ve faaliyetler, uygulanan farklı öğretim yöntem ve teknikler hem olumlu haber değeri taşımakta, hem de eğitim yöneticilerinin dikkatini çekmektedir. Öğrencinin sürece dâhil olduğu tüm yöntemler eğitim yöneticileri tarafından da fark edilmekte, gazetelere de olumlu haber olarak yansımaktadır. Eğitim yöneticilerinin katıldığı, eğitim öğretim sürecinin niteliğini arttıracak her türlü faaliyet, toplantı, çalıştay, bilgilendirme ve okul ziyaretleri de gazetelere olumlu yansıyan haberler içerisinde bulunmaktadır. Eğitim yöneticilerinin odalarından çıkıp sahaya inmeleri her zaman istenen bir durum olup gazetelerde de dikkat çekici haberler olarak yerini almaktadır.

Eğitim sosyal hayattan bağımsız bir olgu değildir. Bu bağlamda, eğitim yöneticilerinin içinde olduğu etkinlikler, kitap yardımları, kız çocuklarının eğitime devam etmeleri için yapılan kampanyalar, halkın geleneklerine göre yapılan bir aşure ikramı, eğitim yöneticisinin halktan kopmadan toplumsal değerlere saygı duyarak işlerini yerine getirdikleri izlenimini vermekte ve gazetelere de olumlu haberlerle yansımaktadırlar. Eğitim yöneticilerinin bulundukları çevreye duyarlı olmaları, okulun temizliği ve güvenliği ile ilgili tedbirleri almaları, bu konuda milli eğitimin beyaz bayrağına layık görülmeleri, yine okul yöneticisinin sadece eğitim anlamında değil, çevre duyarlılıkları ve okul güvenliği bağlamında da etkin yönetici olmaları gerektiğini, bu konulardaki haberlerin de basına olumlu olarak yansıdığını göstermektedir. Eğitimde ödüllendirmenin gücünü bilen yöneticiler, başarılı öğretmenleri ödüllendirmekte, bu da basına olumlu haber olarak yansimaktadır.

Eğitim yöneticileri ile ilgili gazetelere yansıyan olumsuz haberlerin toplumda da infial yaratacak olan cinsel istismar, taciz haberleri olduğu ve bunun yanında hem ögrenciye hem öğretmene şiddet ve mobbing uygulayan yönetici ve öğretmenlerin de bulunduğu haberler söylenebilir. Cinsel istismar, taciz, şiddet ve mobbing haberleri adliyeye intikal etmiş vakalar olup içlerinde tutuklananlar da olmuştur. Erdemli (2018), öğretmene yönelik şiddet ile ilgili olarak basına yansıyan haberleri araştırdığı çalışmasında 2010 yılından 2015 yılına kadar öğretmene yönelik şiddet olaylarının \%2'den \% 32'ye çıktığını belirtmektedir. Bu tür haberler toplumun geleceğini şekillendiren eğitim yöneticilerinin imajını zedelemekte, itibarını düşürmektedir.

Teyfur (2014), okullarla ilgili şiddet haberlerini irdelemiştir. Araştırmanın birinci zaman aralığı olan 1 Mart 1998-1 Mart 1999 aralığında çıkan haberlerin içeriğinde öğretmenler tarafindan 
öğrencilere karşı uygulanan şiddet ön plana çıkmıştır. Bir sonraki zaman aralığı olan 1 Mart 2003-1 Mart 2004 döneminde ise haberlerin içeriğinde öğretmenlerin yanı sıra öğrenci velilerinin de şiddete konu olduğu ortaya çıkmıştır. Okulların önemli sorunlarından bir olan taciz olaylarının araştırma yapılan dönemler arası karşılaştırmalarda \% 5,97'den \% 9,15'e çıktığ görülmüştür. Yine bu dönemlerde okullardaki bıçaklama olayları ile ilgili haberlerin \% 1,49'dan \% 4, 23'e uyuşturucu olayları ile ilgili haberlerin \% 4,48'den beş yıl sonra \% 10,56'ya çıktığı görülmektedir.

Çetin ve Demirkasımoğlu (2015), kamu okullarında görev yapan öğretmen ve yöneticilerin etik ve etik dışı davranışlarının basında yer alma sıklığını, bu davranışlardan kimlerin nasıl etkilendiğini ve bu davranışların sonuçlarının neler olduğunu belirlemeye çalışmışlardır. Araştırmada 2008-2013 yılları arasında basına yansıyan haberlerden 35'inin etik, 109'unun ise etik dışı haberler olduğu yıllar içinde de bu sayıların artmış olduğu sonucuna varılmıştır. Bu çalışmada eğitim yöneticileri ile ilgili olarak basına yansıyan olumsuz içerikteki haber sayısı az olsa da, her olayın basına yansımadığı gerçeğini unutmamak gerekmektedir. Ayrıca toplumu şekillendiren kurumların yöneticilerinin bu tür hataları asla yapmamaları da istenen bir durumdur.

Bu çalışmada cinayet haberleri kategorisinde yer alan haberde her ne kadar cinayet haberleri içindeki kurban okul müdürü ise de bu haber eğitim yöneticilerinin gazetelere yansıyan olumsuz haberler teması içinde yer almıştır. Bu temadaki haberler birbiri ile bağlantılı olup aslında tek bir haberin farklı süreçlerde basına yansıması resmedilmiştir. Eğitim yöneticileri topluma örnek teşkil etmeleri sebebiyle yöneticilerle ilgili olarak öğrenciyi dövme, herhangi birine hakaret etme, öğrenciyi bir şekilde etiketleme ve etik davranışlara uymayacak şekilde cezalandırma basına olumsuz olarak yansımaktadır. Bu tür haberler sonucunda eğitim yöneticileri ile ilgili soruşturma başlatılarak olay adliyeye intikal etmektedir.

\section{Kaynakça}

Altun, A. (2014). How do students, teachers, and school administrator end up in the news? Öğrenci, öğretmen ve idareci ne yaparsa haber olur?. Journal of Human Sciences, 11(2), 871-893.

Altun, S. A., ve Kirit, G. (2005). Okul yöneticilerinin basındaki imajı. Kuram ve Uygulamada Egitim Yönetimi Dergisi, 11(1), 25-46.

Arslan, A. (2004). Medyanın birey, toplum ve kültür üzerine etkileri. Journal of Human Sciences, 1(1).

Başaran, İ.E. (1996). Eğitim Yönetimi. Yargıcı Matbaası.

Berkant, H. G., ve Cömert, M. (2013). Günlük gazetelerdeki eğitimle ilgili haberlerin incelenmesi. Kahramanmaraş Sütçü İmam Üniversitesi İktisadi ve İdari Bilimler Fakültesi Dergisi, 3(2), 25-44.

Blackmore, J., ve Thorpe, S. (2003). Media/ting change: The print media's role in mediating education policy in a period of radical reform in Victoria, Australia. J. Education Policy, 18(6), 577-595.

Blackmore, J., ve Thomson, P. (2004). Just 'good and bad news'? Disciplinary imaginaries of head teachers in Australian and English print media. Journal of education policy, 19(3), 301-320.

Creswell, J. W. (2013). Beş Yaklaşıma Göre Nitel Araştırma ve Araştırma Deseni [Qualitative Inquiry \& Research Design Choosing Among Five Approaches].(Mesut Bütün \& Selçuk Beşir Demir, Çev. Ed.). Siyasal Publishing. 
Çetin, S. K., ve Demirkasımoğlu, N. (2015). Öğretmen ve Yöneticilerin Etik ve Etik Dış1 Davranışlarının Basına Yansımaları. Mugla Sitki Kocman University Journal of Social Sciences, 34 .

Erdemli, Ö. (2018). Öğretmene Yönelik Şiddet: Medyaya Yansıyan Olayların İncelenmesi. Retrieved from https://www.researchgate.net/publication/325853703_.

Gavish, T., ve Oplatka, I. (2012). Educational leadership in the era of mass media: state, consequences and repercussions. School Leadership \& Management, 32(1), 73-89.

Gazete Tirajları, (2017). http://gazetetirajlari.com/2017/09

Gökçe, O. (2006). İçerik Analizi Kuramsal ve Pratik Bilgiler. Siyasal Kitabevi.

McMillan, J. H. (2000). Educational research: Fundamentals for the consumer (4th ed.). Addison Wesley Longman, Inc.

MEB. (2016).Eğitim-öğretim hizmeti verenler için etik ilkeler.

http://personel.meb.gov.tr/meb_iys_dosyalar/2016_06/02032141_mesleki_etik_ilkeler.pdf

Medyatava (2017). http://www.medyatava.com/tiraj

Merriam, S. B. (2013). Nitel araştırma. Desen ve Uygulama İçin Bir Rehber.(Çev. Editörü: Selahattin Turan). Nobel Akademik Yayınc1lık.

TDK (2018). http://www.tdk.gov.tr/

Teyfur, M. (2014). Evaluation of the Events Reported in the Media about Violence in Schools. Elementary Education Online, 13(4), 1311-1330.

Yaylac1, A. F., ve Beldağ, A. (2018). Değerler eğitimi ve güncel tartışmalar: gazete haberlerine ilişkin bir eleştirel söylem analizi. Sakarya University Journal of Education, 8(1), 139-155.

Yıldırım, A. ve Şimşek, H. (2013). Sosyal Bilimlerde Nitel Araştırma Yöntemleri. Seçkin Yayıncılık.

Yılmaz, E. (2006). Okullardaki örgütsel güven düzeyinin okul yöneticilerinin etik liderlik özellikleri ve bazı değişkenler açısından incelenmesi (Doctoral dissertation, Selçuk Üniversitesi Sosyal Bilimler Enstitüsü).

Yin, R. K. (2009). Case Study Research: Design and Methods (Fourth Edition). SAGE Publications, Inc. 